\title{
Life-cycle economic model of small treatment wetlands for domestic wastewater disposal
}

\author{
David Steer $^{\mathrm{a}, *}$, Todd Aseltyne ${ }^{\mathrm{a}, 1}$, Lauchlan Fraser ${ }^{\mathrm{b}, 2}$ \\ ${ }^{a}$ Geology Department, The University of Akron, Akron, OH 44325-4101, USA \\ ${ }^{\mathrm{b}}$ Biology Department, The University of Akron, Akron, OH 44325-3908, USA
}

Received 30 May 2002; received in revised form 15 October 2002; accepted 13 December 2002

\begin{abstract}
Total system life costs (capital cost and ecological based on released pathogens) were modeled for two-cell domestic treatment wetland systems and compared to costs of traditional and emerging technology systems. Small treatment wetlands that were operationally effective for 20-years had net present value (NPV) costs \$500-3000 less than those of sand filter systems. The same treatment wetlands were modeled as releasing $\sim 4$ times pathogens, thus having a much higher ecological cost than sand filter systems. Wetland systems modeled using the highest possible pathogen treatment efficiencies still released $\sim 2$ times the pathogens of sand filter systems. Treatment wetlands must function a minimum of 10 years before replacement in order to remain equivalent in cost to a sand filter lasting 20 -years using a $6.25 \%$ discount rate. The maximum allowable installation costs for any alternative system (with no annual expenses) were $\$ 6675-7700$ if required to be equal in total system NPV costs to wetlands. NPV costs were found to be particularly sensitive to uncertainties in installation and maintenance costs. Modeling indicated that the capital savings realized using wetland systems could be used to modify the simple 2-cell design such that both capital and ecological loads delivered to the environment could be minimized. Wetlands may provide a more sustainable option for communities if effluent is centralized and treated in an appropriately scaled wetland system.
\end{abstract}

(C) 2003 Elsevier Science B.V. All rights reserved.

Keywords: Treatment; Wetlands; Domestic; Cost; Economic model

* Corresponding author. Tel.: +1-330-972-2099; fax: +1330-972-7611.

E-mail addresses: steer@uakron.edu (D. Steer), taa3@uakron.edu (T. Aseltyne), 1fraser@uakron.edu (L. Fraser).

1 Tel.: +1-330-972-7705

${ }^{2}$ Tel.: +1-330-972-6141; fax: +1-330-972-8445

\section{Introduction}

Constructed wetlands for wastewater treatment have become more frequently considered as a waste management option in the past 30 years based on performance, lower maintenance, the appeal of natural technology and presumed lower installation and operation costs (Brix, 1994; Kadlec and Knight, 1996; USEPA, 1999; Mitsch and Gosselink, 2000). Treatment wetlands for single- 
family domestic wastewater are typically subsurface flow systems. These designs consist of a septic tank with two or more wetland cells composed of a gravel substrate anchored with vegetation (USEPA, 1999). These natural systems are known to effectively mitigate a variety of pollutants including fecal coliform, total suspended solids and biochemical oxygen demand (BOD) (Wood, 1995; Nokes et al., 1999; Mitsch and Gosselink, 2000). Treatment wetlands gained favor for use in regions with impermeable or hydric soils that do not support more traditional natural soil-column filtration. Several studies cite lower installation costs of treatment wetlands as an advantage for using these systems in rural settings where traditional centralized sewage treatment is not an economical option (Reed, 1993; Cooper et al., 1996; Neralla et al., 2000; Ogden, 2001).

Full system costs over the projected life of wetland treatment systems are not adequately explored. In most cases, the costs of the systems are based only on capital costs incurred during construction and maintenance costs expended during operation. The effective life spans of these systems are generally not considered due to uncertainties associated with natural variables that exist with wetlands such as loading rate, size and maintenance (Kadlec and Knight, 1996; Mitsch and Gosselink, 2000). Any potential aesthetic, cultural or ecological benefits gained from using wetlands are acknowledged (Mitsch and Gosselink, 2000), but not quantified in a costbenefit sense for treatment wetlands. Also not factored into evaluations of the domestic treatment wetlands overall benefits or costs are the known large range of pathogen removal efficiencies (Bhamidimarri et al., 1991; Neralla et al., 2000; Steer et al., 2002) resulting in variable pollutant loads delivered to the environment.

Other comparable systems used where soil filtration is not an option also employ a septic tank for the primary treatment of wastewater, but the secondary treatment option varies depending on soil conditions, climate and local regulations. One such system employs a sand filter and relies on vertical percolation of the wastewater through sand before being recollected and discharged (TCSOWG, 2001). Hybrid systems that include aeration units, peat filters or other new technology are also emerging as options for homeowners in rural settings though the costs of these systems vary widely. Though these systems have capital costs that can be readily compared to natural alternatives such as wetlands, they also lack detailed assessments of ancillary life cycle, operational, aesthetic, cultural or environmental costs or benefits. Since actual costs are perhaps the prime factor for homeowners selecting a system, detailed comparisons of full costs (and benefits) for these treatment options are essential.

Complete evaluation of domestic wastewater treatment options must consider existing regulations and water resource management policies. There is dichotomy between the desires of homeowners (low costs) and the needs of watershed managers to meet total maximum daily load requirements currently being developed and implemented throughout the United States. Recent changes in the National Pollution Discharge Elimination System (NPDES) have added to the potential problems regarding treatment wetlands by altering permit criteria and assigning specific effluent standards for surface discharging systems (USEPA, 2001). Therefore, it is necessary to examine the long-term cost of treatment wetlands as compared to alternative systems that may be considered by officials developing watershed management plans. This study compares total system costs and values (capital, societal, and environmental) over the projected life of the system for small domestic treatment wetlands, sand filter systems and emerging technology options. Such information is useful for watershed managers seeking to provide homeowners with cost-effective wastewater treatment options that meet water quality goals.

\section{Methods}

\subsection{Capital costs}

Capital costs (of prime importance to the consumer) and pathogen loads to the environment (of major interest to water resource managers and the EPA) formed the basis of the method of 
valuation and modeling presented here. Treatment option system valuations were explored by first determining the net present value (NPV) of the costs of the systems using the EPA total cost accounting method (TRNCC, 1998) with

$\mathrm{NPV}($ costs $)$

$$
=\sum C(t) /(1+\delta)^{n}-\sum B(t) /(1+\delta)^{n}
$$

$C(t)$ values were the inflation adjusted capital costs associated with initial installation costs, annual maintenance and possible wetland replacement. $B(t)$ were the economic benefits including an ecosystem value of $\$ 14785 / \mathrm{ha} / \mathrm{yr}$ taken from Costanza et al. (1997) and possible aesthetic value of wetlands using costs associated with installing comparable ornamental gardens. $\delta$ was the discount rate and ' $n$ ' was the number of years modeled (from 0 to 20 years). The minimum required wetland life span was determined for a range of discount rates by comparing the NPV cost of wetland replacement to the cost savings that accrued from lower installation costs of wetlands compared to sand filter systems.

Actual expense data for nine single-domicile treatment wetlands (Table 1) constructed in 199899 in western Ohio, USA were used to determine initial costs for typical two-cell wetland treatment systems. The average cost of these wetlands (in 2002 dollars) was approximately $\$ 5665 \pm 600$ and was representative of such systems in the US (White and Shirk, 1998; J. Boddy, Department of Health, Lorain, OH, 2002, personal communication). Annual maintenance and monitoring expenses (2002 dollars) of $\$ 225$ were based on costs incurred for these systems from 1998-2001. The monitoring costs are representative of those that will be incurred for homeowners to comply with NPDES permitting regulations. The regulations require annual pathogen monitoring (fecal coliform, ammonia, BOD, phosphorus, and dissolved oxygen) for surface discharging systems. Costs of occasional replanting of wetlands, removal of invaders and periodic visits to the wetlands by health department personnel are included in the monitoring and maintenance costs. Treatment wetlands were estimated to have an ecosystem valuation of $\$ 85 / \mathrm{yr}$ with a partial system

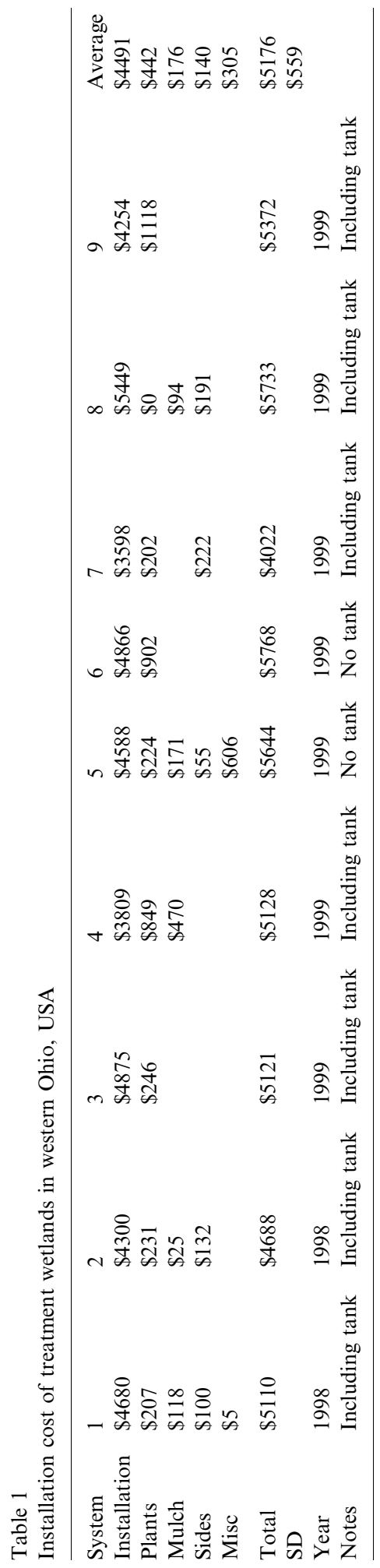


rebuild cost of $\$ 3500$ (2002 dollars). Sand filter installation and annual maintenance costs were considered to be $\$ 7500$ and 130 , respectively based on reports by TCSOWG (2001). Actual costs through 2002 were indexed for inflation using a $3 \%$ annual rate.

NPV costs were modeled using ecosystem and aesthetic valuations for a range of possible scenarios. The aesthetic values of the wetland systems were modeled using three options. In cases where homeowners do not plant ornamental biota or do not perform any annual maintenance there is likely little or no aesthetic value (no aesthetic value assigned). Where great care is taken to plant aesthetically pleasing plants and flowers, the initial value could be as high as that required when planting a large ornamental garden $(\sim \$ 1000$ lump initial value). In other cases the aesthetic value may be smaller, but sustained over the life of the wetland, thus having an NPV that accrues over time (estimated at $\$ 50 / \mathrm{yr}$ ). Aesthetic values of all alternative systems were valued at $\$ 0$ since they were non-ornamental subsurface options. NPV cost savings for ecosystem value were analyzed using two options ( $\$ 0$ and $85 / \mathrm{yr}$ as explained above).

The NPV cost portion of the model allowed calculation of NPV cost for two-cell wetland treatment systems and sand filter systems assuming a maximum effective life of 20 years. The system with the lowest NPV costs was used to determine an equivalent NPV cost for any generic emerging technology option with no additional costs or benefits. The model was also used to determine the minimum wetland life required for this type of system to remain cost effective compared to sand filter systems. All capital cost results were analyzed for sensitivity to input variables of wetland cost, recurring expenditures, aesthetic value, ecosystem value and discount rate.

\subsection{Ecologic impacts}

Total pathogen loads delivered to the environment annually over the life of the system were used to establish a valuation of the ecological impact of the treatment option. The ability of a system to effectively treat wastewater varies over time though the systemic nature of these changes in efficiency is not well known (USEPA, 1993). In the best case, no degradation in efficiency may occur over time (USEPA, 1999). For this study, total loads delivered to the environment were calculated assuming no degradation (best case) and first order degradation (worst case) in the system's ability to reduce pathogens over its lifespan using known output concentrations. Modeled concentrations were calculated by integrating

$C_{\mathrm{i}}(t)=\left(C_{\mathrm{i} 0}+C_{\mathrm{i} 0}(1-\exp (-t / T))\right)$

for the modeled lifespan of the system where, $C_{\mathrm{i}}(t)=$ individual (i) pathogen concentration at a given time $(t) ; C_{\mathrm{i} 0}=$ current average output pathogen concentrations; $T$ was the modeled lifespan. For the no system degradation case, concentrations did not change over time ( $T$ infinite).

Average pathogen concentrations and efficiencies for functional (those not commonly exceeding existing standards) domestic treatment wetlands (Table 2: columns 1 and 3) were taken from Steer et al., 2002. Average treatment efficiencies for sand filter systems as reported by Geller (1997) and Harrison et al. (2000) were used to estimate output concentrations for sand filter systems assuming the same input loads as those delivered to the wetland systems (Table 2: last column). A theoretical wetland was modeled based on pathogen removal efficiencies reported by several researchers (Table 2: column 4). Fecal coliform, ammonia, BOD and phosphorus loads were normalized by the maximum permissible load over the life of the system using proposed EPA standards (USEPA, 2001) for systems discharging to surface waters (Table 2, column 2).

The ecological cost portion of the model allowed calculation of normalized pathogen loads delivered to the environment during a 20 -year period for two-cell wetland treatment systems and sand filter systems. The least costly option (based on integrated loads) was used to determine equivalent initial efficiency for any generic emerging technology option that had no annual costs. The model was also used to determine the effect of wetland life on loads delivered. All ecological valuation results were analyzed for sensitivity to 
Table 2

Output pathogen concentrations and system efficiencies

\begin{tabular}{llllll}
\hline & $\begin{array}{l}\text { Wetlands output } \\
\text { concentrations }^{\mathrm{a}}\end{array}$ & $\begin{array}{l}\text { Proposed EPA } \\
\text { standard }\end{array}$ & $\begin{array}{l}\text { Wetland, } \\
\%_{\text {Eff }}^{\mathrm{a}}\end{array}$ & $\begin{array}{l}\text { Wetland, } \\
\% \text { High Eff }\end{array}$ & $\begin{array}{l}\text { Sand filter, } \\
\% \text { Eff }\end{array}$ \\
\hline Fecal (counts/100 ml) & $750 \pm 865$ & 2000 & 88 & $99^{\mathrm{b}}$ & $99.8^{\mathrm{e}}$ \\
Ammonia $(\mathrm{mg} / \mathrm{l})$ & $14.1 \pm 10.8$ & 1.5 & 56 & $70^{\mathrm{c}}$ & $90^{\mathrm{f}}$ \\
BOD $_{5}(\mathrm{mg} / \mathrm{l})$ & $14.4 \pm 12.6$ & 15 & 70 & $90^{\mathrm{b}}$ & $90^{\mathrm{f}}$ \\
$P(\mathrm{mg} / \mathrm{l})$ & $2.6 \pm 3.9$ & 1.5 & 80 & $97^{\mathrm{d}}$ & $90^{\mathrm{f}}$ \\
\hline
\end{tabular}

a Steer et al. (2002).

b Neralla et al. (2000).

c Koottatep and Polprasert (1997).

d Maehlum et al. (1995).

${ }^{\mathrm{e}}$ Harrison et al. (2000).

f Geller (1997).

input variables of pathogen concentrations and efficiencies.

\section{Results}

\subsection{Capital costs}

Net present costs for wetland treatment systems were from $\sim \$ 500$ to $\sim \$ 3000$ less than sand filter systems over a range of discount rates (Table 3). Several trends were apparent when NPV costs were analyzed using a representative $(10 \%)$ discount rate (Fig. 1). Two-cell domestic wetlandssand filter NPV costs differences were the lowest $(\sim \$ 1000)$ if the wetland was allocated no aesthetic or ecosystem value (Fig. 1; curve c compared to g). The general trend of these two curves also indicated that the difference in the NPV costs decreased only slightly as lifespan increased. The wetland systems were most cost effective ( $\sim$
\$3000) if annual valuations were allocated to both aesthetic and ecosystem value (Fig. 1; curve a compared to g).

All modeling results were sensitive to annual costs. The option that used a $\$ 1000$ lump sum aesthetic value with no ecosystem value had an intermediate total system cost (Fig. 1; curve b). If annual wetland monitoring costs increased by $50 \%$ (to $\$ 325 / \mathrm{yr}$ ), wetland systems with no aesthetic or ecosystem value were found to have slightly higher costs than sand filter systems (Fig. 1; f compared to g). Other options using different aesthetic and ecosystem valuations continued to show that wetland systems had lower NPV costs than sand filter systems (Fig. 1; curves a-e compared to g). If the wetland monitoring costs were increased to $\sim \$ 500$, all wetland options were more costly than sand filter systems. Initial wetland costs were not a key variable in these calculations. The initial wetland costs must increase to $\sim \$ 6500$ (original cost plus $\sim 2$ SDs of

Table 3

\$NPV (Cost Wetland - \$NPV Cost Sand Filter) for 20-year life cycle

\begin{tabular}{|c|c|c|c|c|}
\hline Discount rate & $5.0 \%$ & $10.0 \%$ & $15.0 \%$ & $20.0 \%$ \\
\hline \multicolumn{5}{|l|}{ Option } \\
\hline \$0 Aesthetic, $\$ 0$ Economic & $\$ 500$ & $\$ 1000$ & $\$ 1300$ & $\$ 1500$ \\
\hline \$0 Aesthetic, \$50/yr Economic & $\$ 1500$ & $\$ 2000$ & $\$ 2300$ & $\$ 2500$ \\
\hline \$85/yr Aesthetic, \$50/yr Economic & $\$ 2900$ & $\$ 3000$ & $\$ 3000$ & $\$ 3000$ \\
\hline$\$ 0$ Aesthetic, $\$ 1000$ initial Economic & $\$ 1400$ & $\$ 1900$ & $\$ 2200$ & $\$ 2300$ \\
\hline \$85/yr Aesthetic, \$1000 Economic & $\$ 2800$ & $\$ 2800$ & $\$ 2800$ & $\$ 2800$ \\
\hline
\end{tabular}




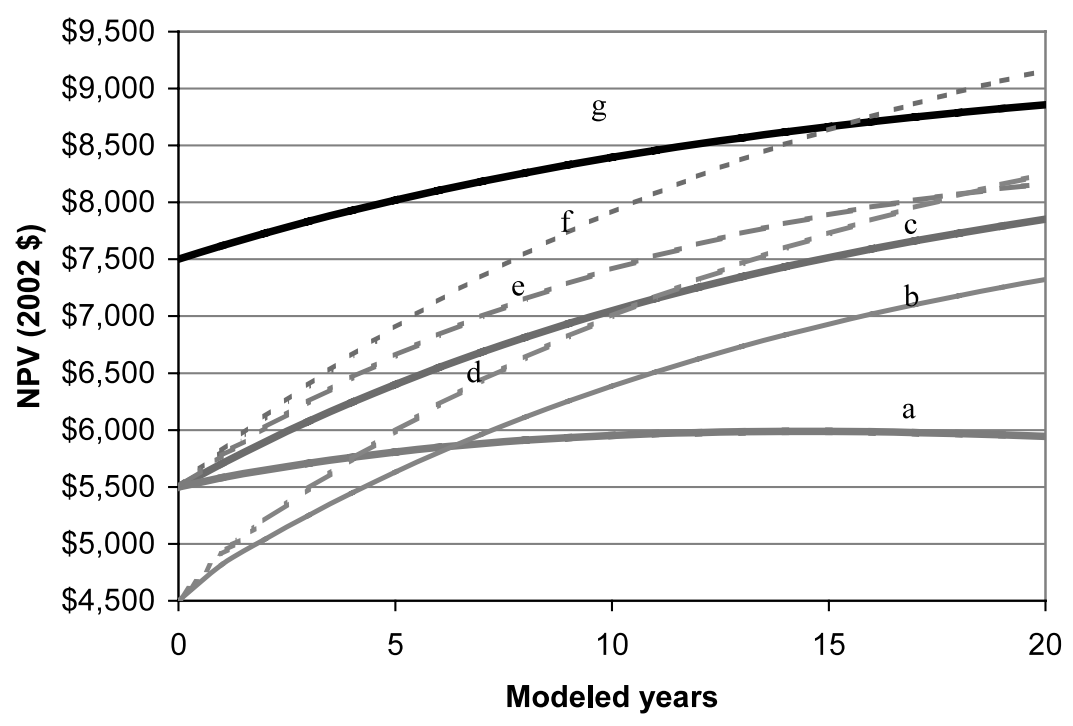

Fig. 1. NPV costs of a treatment wetland with 20- and 10-year lifespan versus a sand filter system using a $10 \%$ discount rate. Curve a: $\$ 85 / \mathrm{yr}$ ecosystem value and $\$ 50 / \mathrm{yr}$ aesthetic value; Curve $b$ : $\$ 0$ ecosystem and $\$ 1000$ lump sum aesthetic; Curve c: $\$ 0 / \mathrm{yr}$ ecosystem value and $\$ 0 / y r$ aesthetic value; Curve $d$ : curve c with higher monitoring costs; Curve e: curve a with higher monitoring costs; Curve $f$ : curve b with higher monitoring costs; Curve $g$ : sand filter system.

the cost) before wetland monitoring increased the NPV cost of the wetland to that of the sand filter system. Also, any alternative system with an initial cost of $\$ 7700$ that incurred no operation and maintenance expenses accrued the same life costs as an average wetland system (Fig. 1: curve c) with monitoring costs over a 20 -year effective life.

The maximum effective lifespan for the wetland system to be cost effective compared to sand filter systems varied from 3 to 20 years depending on the discount rate (Fig. 2). As expected, the NPV cost of wetland system repair decreases over time (Fig. 2: curves $\mathrm{a}-\mathrm{d}$ ). At a $10 \%$ discount rate, the NPV cost of replacing the wetland system is $\sim \$ 500$ if the wetland system functions for 20 years $(T=20)$. The initial savings in wetland NPV costs actually decreases over time (Fig. 2: curves e-h). At a 10\% discount rate, the treatment wetlands could be repaired after 8 years at a net NPV equal to that of the sand filter system (Fig. 2; intersection of curves $\mathrm{e}$ and $\mathrm{b}$ ). At the highest modeled discount rate $(20 \%)$ the wetland system need only function for $\sim 3$ years before replacement (Fig. 2; intersection of $\mathrm{d}$ and $\mathrm{h}$ ). A discount rate of $\sim 6.5 \%$ allowed wetland replacement at approximately 10 years (one-half the maximum expected life of the wetland and sand filter systems).

The modeled life spans are sensitive to changes in initial wetland installation costs or monitoring costs. Any increase in initial wetland installation costs decreased the NPV savings computed over the total modeled period (resulted in a downward static shift of all dashed lines in Fig. 2). As NPV savings decreased, the intersection of the NPV cost of replacement curves and the NPV value of savings migrated to longer minimum required life spans. Increased monitoring costs (of wetland systems relative to sand filter systems) resulted in convergence of the NPV savings curves and also increased the maximum required wetland life span.

\subsection{Ecologic impacts}

Sand filter systems annually delivered lower pathogen loads to the environment than wetlands systems regardless of the effective life of the system (Fig. 3; curves a and b compared to all others). If no system degradation in treatment efficiency occurred, sand filter systems released $\sim 25 \%$ of the load (in terms of normalized concentrations of pathogens) of those delivered by average wetland 


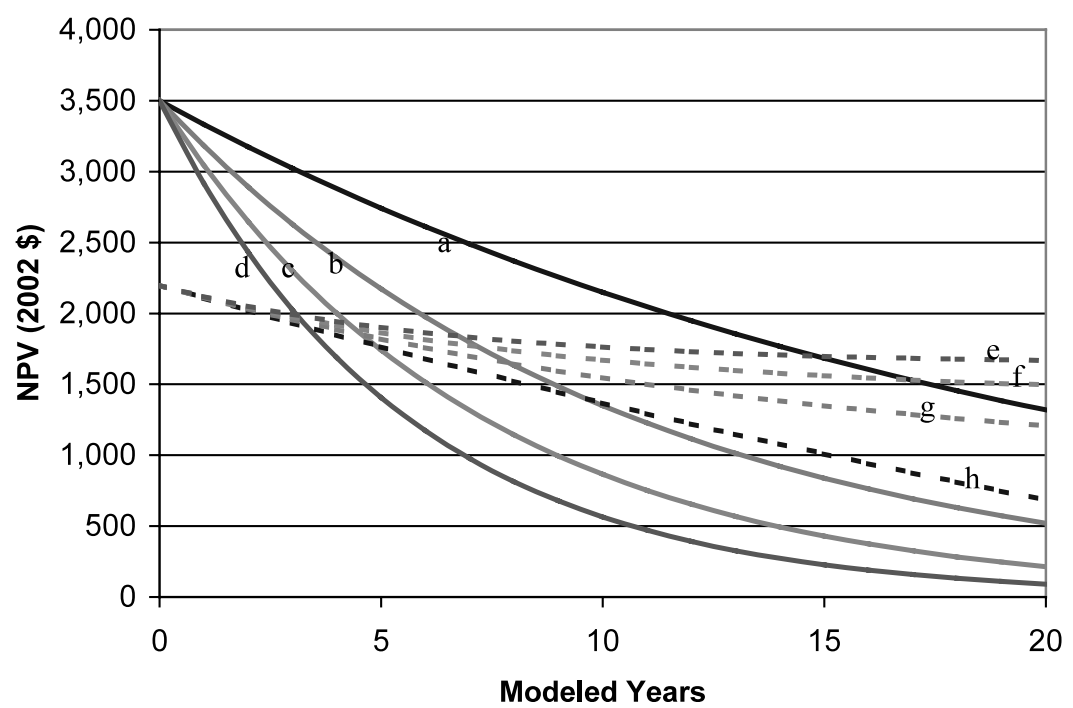

Fig. 2. Solid line denote NPV of replacement cost for a wetland system for a variety of discount rates (a, 5\%; b, 10\%; c, 15\%; d, 20\%). Dashed lines show NPV cost savings available (sand filter - wetland system) over the modeled lifespan for various discount rates (e, $5 \%$; f, 10\%; g, 15\%; h, 20\%).

systems (Fig. 3; curve a compared to curves f). If system efficiency decreased over time, annual total loads delivered to the environment were $<30 \%$ those of average wetland systems (Fig. 3; curves b compared to $h$ ). Though these results were most sensitive to ammonia outputs, sand filter systems

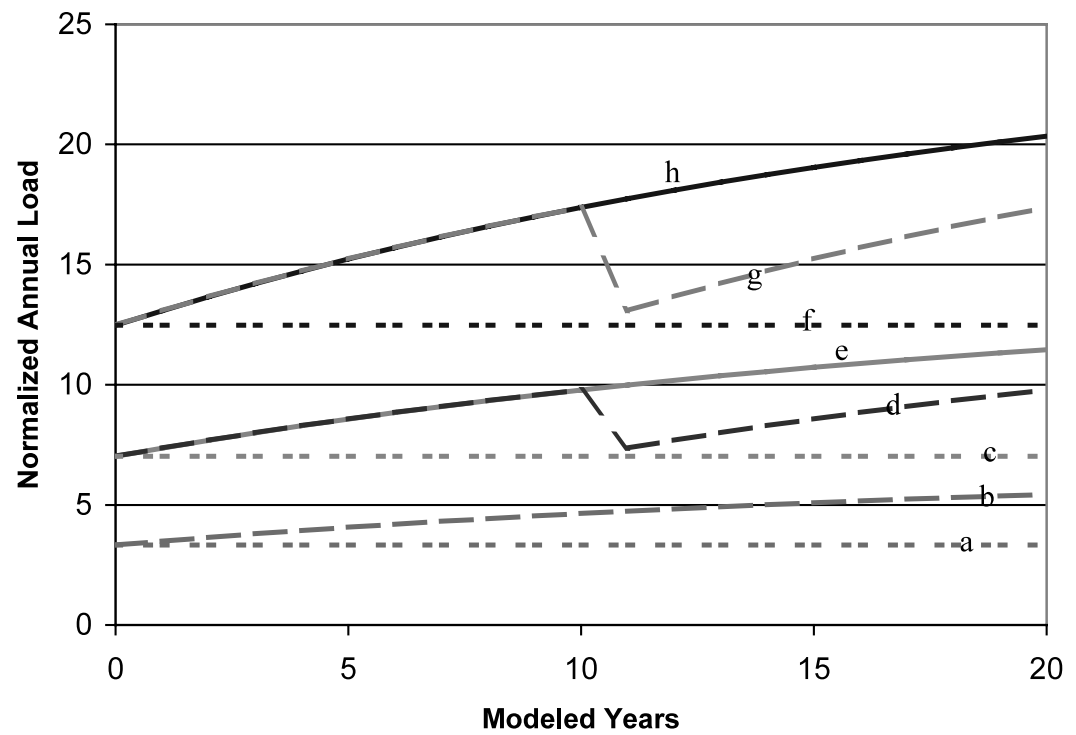

Fig. 3. Ecological costs (in terms of normalized loads delivered to the environment) Curve a: sand filter system with constant effluent discharge concentrations; Curve b: 1st order degradation for sand filter; Curve $c$ : high efficiency wetland with constant effluent discharge concentrations; Curve $d$ : high efficiency wetlands with 10-year life span and 1st order degradation; Curve e: high efficiency wetlands with 20-year life span and 1st order degradation; Curve $f$ : average wetland system with no system degradation; Curve g: average wetland with 10-year life span and 1st order degradation; Curve h: average wetland with 20-year lifespan and 1st order increase in output concentrations. 
still only delivered $40 \%$ of the fecal coliform, BOD $_{5}$ and $P$ loads of wetlands if ammonia was removed from consideration. Output concentrations of wetlands were lower in the 10-year lifespan model, but still exceeded those of sand filter systems throughout the 20 years modeled (Fig. 3; curve g compared to $b$ ).

These results were a function of wetland system efficiency. Simple inspection of changes to normalized concentrations (Fig. 3) indicated that these simple two-cell wetland systems did not achieve output levels found in sand filter systems (even when there was no degradation in system efficiency over time). However, treatment wetlands are known to function with a large range of efficiencies. Neralla et al. (2000) documented 90$99 \%$ fecal coliform and $80-90 \% \mathrm{BOD}_{5}$ treatment efficiencies in a study of seven domestic treatment wetlands. The upper end of this range was commensurate with the sand filter data reported by Harrison et al. (2000) and Geller (1997). Phosphorus reductions modeled here fell within the $80-97 \%$ range cited for other regions (Maehlum et al., 1995; Urbanc-Bercic and Bulc, 1995). Ammonia levels were only slightly lower than the $\sim 70 \%$ efficiency typically reported in the literature (Gersberg et al., 1983; Hammer and Knight, 1994; Koottatep and Polprasert, 1997). Modeling of output loads using the most optimistic (highest reported) treatment efficiencies for wetlands (Table 2: High Efficiency Wetland) indicated that sand filters still only delivered $\sim 50 \%$ of the pathogens to the environment as well functioning wetland systems (Fig. 3; curves a and b compared to $\mathrm{c}$ and e, respectively). Any alternative system must reduce pathogens with greater efficiencies than those of sand filters before they can be directly compared.

\section{Discussion}

\subsection{NPV costs}

The wetland system lifespan must be maximized in order for this type of system to remain cost effective from a capital cost perspective. The capital portion of the model clearly indicated that wetlands had much lower NPV costs than sand filter systems when analyzed over a 20 -year life. NPV costs for wetlands remained several thousand dollars less than sand filter systems even if using very recent estimates of $\$ 7000$ for installation of 2-cell systems in Ohio (J. Boddy, Department of Health, Lorain, personal communication). In isolated cases, these wetland systems have been shown to fail within 2-3 years of the installation (Mann, 1990; Steiner and Combs, 1993). As shown in Fig. 2, at a 10\% discount rate the wetland option must have an effective life of $\sim 8$ years or greater to be cost equivalent or less expensive than the sand filter option. Higher discount rates allowed for earlier system failure, lower discount rates required longer life spans. The replacement wetland had to be functional for the remainder of the 20-year lifespan to remain the cost effect option (it could not be replaced more than once).

Annual costs played a major role in the system NPV cost comparisons. Actual monitoring costs will vary from region-to-region. The actual number of samples required to adhere with NPDES permits depends directly on the system performance. If the system fails to meet one or more monitored loads, additional sampling above the mandated 1-year frequency will be required until an individual system meets effluent standards. Additional sampling incurs additional, but wetland-specific costs, that ultimately raised total system costs to the homeowner in this study.

Alternative treatment systems (excluding wetlands and sand filters) could be selected based on a maximum allowable installation cost. The maximum cost modeled here was purely a function of the total cost of the wetland with an effective life of 20 years. If the alternative treatment system had an installation cost of $\$ 6675$ and no annual costs, the total NPV cost after 20 years was equal to that of a treatment wetland. However, no such low cost systems are known to be in use or wetlands would not likely be an attractive option. In comparison to sand filter systems, any alternative with a NPV of $\$ 8860$ was cost effective from a capital perspective. Typical mound systems range in capital costs from $\$ 9000-15000$ depending on soil conditions (Henneck et al., 2001). Highly efficient membrane 
systems or chemical treatment options may have significantly higher initial costs. These capital costs do not include any annual maintenance that has been shown to be the limiting capital factor to any system.

\subsection{Ecological costs}

Wetland treatment systems were clearly more costly to the environment than sand filter systems based on the modeling presented here. Many wetland treatment systems have been shown to effectively reduce wastewater effluents for over 20 years (Mitsch and Gosselink, 2000). However, wetland lifespan was not found to be a significant factor when analyzing total costs (loads) to the environment compared to sand filter systems. Shorter wetland lifespan actually decreased the overall impact on the environment if the wetland treatment system was refurbished (and essentially reset to initial average levels of function). That result was directly a function of differences between output pathogen concentrations of wetland systems compared to sand filter systems.

Under the new NPDES effluent limitations (Table 2), some treatment wetlands that were previously considered to be functioning effectively for many years are failing in at least one effluent category (Mann, 1990; Bhamidimarri et al., 1991; Steiner and Combs, 1993; Terry, 1993; Jenssen et al., 1993). Nitrogen (as found here in the ammonia data) and phosphorous are the most frequent effluents to fail to meet discharge standards. The nitrification of ammonia $\left(\mathrm{NH}_{3}\right)$ is limited by the anaerobic conditions present in wetlands (USEPA, 1999). Aeration units added to a wetland system may increase available oxygen needed to drive ammonia-reducing reactions and thus reduce overall nitrogen loads to the environment. Phosphorus outputs could be reduced (thus improving efficiency) through harvesting and removal of plants rather than allowing them to degrade naturally in the wetland (Davies and Cottingham, 1993; Kadlec and Knight, 1996). These changes to wetland treatment system design, operation and maintenance may lower ecological costs of wetlands near to those of sand filter systems.

\subsection{Combined analysis}

Long-term capital savings achieved by choosing a wetland treatment system (over a sand filter system) could be used to improve the efficiency of the wetlands. For a 20-year lifespan wetland, fixed costs of installation can increase by $\$ 500-3000$ before the long-term costs of wetlands approach those of sand filter systems (Table 3). The cost of an aeration unit $(\sim \$ 900)$ added to the wetland system to reduce ammonia would still keep the NPV of the wetland system well below those of the sand filter system. However, aeration units have other long-term economic consequences. These units add mechanical components to an otherwise completely natural system (wetlands are gravity driven with no mechanical parts). Mechanical components will increase annual expenditures through electrical and routine maintenance costs. On the other hand, aeration units can reduce pathogens entering the wetlands by $85-90 \%$ and may result in an additional positive ecological impact above those modeled. Aeration units also allow oxidation of materials at rates that will likely reduce pumping requirements for the septic tank and thus partially offset annual maintenance expenditures. As shown above, these annual costs must be minimized over the lifespan of the wetland system in order for it to remain a viable alternative for homeowners. Reduction of phosphorus through harvesting also increases annual maintenance cost (labor), though the actual expenditure would be minimal if completed by the homeowner.

Though not explicitly modeled here, another important factor in an evaluation of these systems deals with which treatment option is most sustainable as population density increases. The environmental impact to a watershed from effluent originating from any individual system may be minor. However, if similar discharges were allowed from a subdivision with many homes, the impact of these pathogen loads could be unacceptably large. In a moderate sized housing development (30-50 homes), sand filter systems have a clear advantage over individual wetland systems because of their lower effluent discharge concentrations. The NPV cost of a large system is likely prohibitively high due to the high fixed costs of 
high-grade sands needed for the system (TCSOWG, 2001). Wetland systems are highly scalable and are used throughout the world in small communities (Lowe, 1990; Mitchell et al., 1990; Urbanc-Bercic and Bulc, 1995; Schutes, 2001). Wetland systems use much less expensive materials in their construction (gravels, native plants and local clay). In fact, many constructed wetland systems in the United States are designed for municipal loads (Cole, 2001) where the cost savings is much higher than even those modeled for small individual systems. As such, the scalability of treatment wetland systems coupled with capital cost saving that can be used to further reduce loads making them a viable choice for rural wastewater treatment.

\section{Conclusions}

The results of this modeling are of direct relevance to water resource managers balancing the needs of consumers with the needs of the watershed. Treatment wetland NPV costs were up to $\$ 3000$ less than comparable sand filter systems. These capital savings came at an $\sim 4$ times higher ecological cost when analyzed over a 20-year lifespan. NPV costs were strongly influenced by installation cost, annual cost and the effective life of the wetland before replacement was required. A 10-year effective life was required for the NPV cost of the treatment wetland to equal a sand filter over 20 years at a $6.25 \%$ discount rate. Alternative systems that have a 20 -year effective life are cost effective compared to wetlands if they have no annual operation or maintenance costs and can be installed for less than \$6675-8660 depending on the lifespan of the wetland system and the discount rate. Ecological impacts of treatment wetlands could be minimized if a portion of the initial capital savings were reinvested in components that improve overall pathogen treatment efficiency. Additional savings in cost may be achievable if developments pool resources and build appropriately scaled large wetland systems. Such improvements may ultimately save the consumer funds and reduce the overall impact of domestic effluent releases to the environment.

\section{Acknowledgements}

The authors would like to thank Beth Seibert and James Boddy for providing cost data of treatment wetlands in Ohio. The authors also thank several anonymous reviewers for their comments that greatly improved the final manuscript. This project was funded by a grant from the Ohio Environmental Protection Agency and the United States Environmental Protection Agency under Section 319(h) of the Clean Water Act.

\section{References}

Bhamidimarri, R., Shilton, A., Armstrong, I., Jacobson, P., Scarlet, D., 1991. Constructed wetlands for wastewater treatment: the New Zealand experience. Wat. Sci. Tech. 24 (5), 247-253.

Brix, H., 1994. Use of constructed wetlands in water pollution control: historical development, present status, and future perspectives. Wat. Sci. Tech. 30 (8), 209-223.

Cole, S., 2001. The emergence of treatment wetlands. Env. Sci. Tech. 32 (9), 218A-223A.

Cooper, P.F., Job, G.F., Green, M.B., Shutes, R.B.E., 1996. Reed Beds and Constructed Wetlands for Wastewater Treatment. Water Research Centre Publications, Swindon, UK, p. 154.

Costanza, R., d'Arge, R., de Groot, R., Farber, S., Grasso, M., Hannon, B., Limburg, K., Naeem, S., O’Neill, R.V., Paruelo, J., Raskin, R.G., Sutton, P., van den Belt, M., 1997. The value of the world's ecosystems services and natural capital. Nature 387, 253-260.

Davies, T.H., Cottingham, P.D., 1993. Phosphorus removal from wastewater in a constructed wetland. In: Constructed Wetlands for Water Quality Improvement. CRC Press/ Lewis Publishers Inc, Boca Raton, Florida, pp. 315-320.

Geller, G., 1997. Horizontal flow systems in the German speaking countries: summary of long-term scientific and practical experiences: recommendations. Wat. Sci. Tech. 35 (5), 157-166.

Gersberg, R.M., Elkins, B.V., Goldman, C.R., 1983. Nitrogen removal in artificial wetlands. Wat. Sci. Tech. 17 (9), 10091014.

Hammer, D.A., Knight, R.L., 1994. Designing constructed wetlands for nitrogen removal. Wat. Sci. Tech. 29 (4), 1527.

Harrison, R.B., Turner, N.S., Hoyle, J.A., Krejsl, J., Tone, D.D., Henry, C.L., Isaksen, P.J., Xue, D., 2000. Treatment of septic effluent for fecal coliform and nitrogen in course textures soils: use of soil-only and sand filter systems. Wat. Air Soil Poll. 124, 205-215.

Henneck, J., Axler, R., McCarthy, B., Monson Geerts, S., Heger Christopherson, S., Anderson, J., Crosby, J., 2001. 
Onsite treatment of septic tank effluent in Minnesota using SSF constructed wetlands: performance, costs and maintenance. In: On-site Wastewater Treatment. Proceedings of the Ninth Annual Symposium on Ind. Small Comm. Sewage Systems, ASAE. St. Joseph, MO.

Jenssen, P.D., Maehlum, T., Krogstad, T., 1993. Potential use of constructed wetlands for wastewater treatment in northern environments. Wat. Sci. Tech. 28 (10), 149-157.

Kadlec, R.H., Knight, R.L., 1996. Treatment Wetlands. Lewis Publishers, New York, p. 893.

Koottatep, T., Polprasert, C., 1997. Role of plant uptake on nitrogen removal in constructed wetlands located in the tropics. Wat. Sci. Tech. 36 (12), 1-8.

Lowe, N.R., 1990. The Need for Hydrophyte-based Systems in the Treatment of Wastewater from Small Communities. Constructed Wetlands in Water Pollution Control (Advances in Water Pollution Control no. 11). Pergamon Press, Oxford, pp. 373-381.

Mann, R.A., 1990. Phosphorous Removal by Constructed Wetlands: Substratum Adsorption. Constructed Wetlands in Water Pollution Control (Advances in Water Pollution Control no. 11). Pergamon Press, Oxford, pp. 97-105.

Maehlum, T., Jenssen, P.D., Warner, W.S., 1995. Cold-climate constructed wetlands. Wat. Sci. Tech. 32 (3), 95-101.

Mitsch, W.J., Gosselink, J.G., 2000. Wetlands, third ed.. Wiley, New York.

Mitchell, D.S., Breen, P.F., Chick, A.J., 1990. Artificial wetlands for treating wastewaters from single family households and small communities. In: Constructed wetlands in water pollution conrol (Advances in Water Pollution Control no. 11). Pergammon Press, Oxford, pp. 383-389.

Neralla, S., Weaver, R.W., Lesikar, B.J., Persyn, R.A., 2000. Improvement of domestic wastewater quality by subsurface flow constructed wetlands. Biores. Tech. 75, 19-25.

Nokes, R.L., Gerba, C.P., Karpiscak, M.M., 1999. Reduction of enteric organisms in small-scale, subsurface flow constructed wetlands. In: Means, J.L., Hinchee, R.E. (Eds.), Wetlands and Remediation: Wastewater Remediation and Treatment. Battelle Press, Columbus, OH, pp. 195203.

Ogden, M.H., 2001. Atmospheric carbon reduction and carbon sequestration in small community wastewater treatment systems using constructed wetlands. In: On-site Wastewater Treatment. Proceedings of the Ninth Annual Symposiun on Ind. Small Comm. Sewage Systems, ASAE, St. Joseph, MO.
Reed, S.C., 1993. Subsurface Flow Constructed Wetlands for Wastewater Treatment: A Technology Assessment (EPA 832-R-93-008). USEPA, Washington, DC.

Schutes, R.B.E., 2001. Artificial wetlands and water quality improvement. Envron. Int. 26, 441-447.

Steer, D., Fraser, L., Boddy, J., Seibert, B., 2002. Efficiency of small constructed wetlands for subsurface treatment of single-family domestic effluent. Ecol. Eng. 18 (4), 429-440.

Steiner, G.R., Combs, D.W., 1993. Small constructed wetlands systems for domestic wastewater treatment and their performance. In: Moshiri, G.A. (Ed.), Constructed Wetlands for Water Quality Improvement. Lewis Publishing, MI, pp. 491-498.

Terry, T.B., 1993. Constructed wetlands wastewater quality improvement at Lynnvale Elementary School. In: Moshiri, G.A. (Ed.), Constructed Wetlands for Water Quality Improvement. Lewis Publishing, MI, pp. 535-540.

TCSOWG, 2001. Decentralized Sewerage System Option, A Summary Report by the Toms Creek Sewerage Options Working Group. Town of Blacksburg, VA. p. 20.

TRNCC. 1998. TNRCC Cost Accounting Software. Env. Mgmt. Accounting Res. Inf. Center. US Environmental Protection Agency, Washington, DC.

Urbanc-Bercic, O., Bulc, T., 1995. Integrated constructed wetland for small communities. Wat. Sci. Tech. 32 (3), 41-47.

USEPA, 1993. Subsurface Flow Constructed Wetlands for Wastewater Treatment: A Technology Assessment (EPA 832-R-93-008). US Environmental Protection Agency, Office of Water, Washington, DC.

USEPA, 1999. Manual: Constructed Wetlands Treatment of Municipal Wastewaters (EPA-625-R-99-010). US Environmental Protection Agency, Office of Research and Development, Cincinnati, $\mathrm{OH}$.

USEPA, 2001. Protection of the Nation's Waters through Effective NRDES Permits: A Strategic Plan (EPA-833-R01-001). US Environmental Protection Agency, Washington, DC.

White, K.D., Shirk, C.M., 1998. Performance and design recommendations for on-site wastewater treatment using constructed wetlands. In: On-site Wastewater Treatment. Proceedings of the Eighth Annual National Symposium on Ind. and Small Community Sewage Systems, ASAE. St. Joseph, MO.

Wood, A., 1995. Constructed wetlands in water pollution control: fundamentals to their understanding. Wat. Sci. Tech. 32 (3), 21-29. 